\title{
Parecer do Consultor Jurídico do DASP.
}

\section{PROCESSO $\mathrm{N}^{\circ} 5.385-66$}

\section{PARECER}

No anexo processo, encaminhado pelo Ministério da Viação e Obras Públicas a êste Departamento, para exame, solicita-se a fixação de critério a ser adotado no cálculo de proventos de aposentadoria, em face dos arts. 21, n 7 , e 31 da Lei $n^{9} 4.345$, de 26-6-64, que dispõem, verbis:

«Art. 21 - Além de aos funcionários do Poder Executivo da União e das autarquias federais, esta lei se aplicará aos servidores:

7) aposentados, bem como aos em disponibilidade, no que couber e na forma da Lei $\mathrm{n}^{\circ} 2.622$, de 18 de outubro de 1955 , cujo pagamento independerá da prévia apostila nos títulos dos beneficiários».

"Art. 31 - Até 31 de dezembro de 1964 , o reajustamento previsto no art. $5^{\circ}$ e os reajustamentos dos proventos dos funcionários aposentados e em disponibilidade a que se refere o art. 21 , item 7 , vigorarão com reduções de modo a que êsses reajustamentos não possatm exceder a $100 \%$ (cem por cento) dos valôres decorrentes da execução da Lei $n^{\circ} 4.242$, de 17 de julho de 1963».

2. A dúvida surgiu, ao se cogitar do reajustamento dos proventos dos aposentados, em face da atual situação do pessoal ativo da Administração do Pôrto
do Rio de Janeiro.

3. Para melhor compreensão do problema, cumpre ressaltar que o sistema de classificação daquela autarquia, aprovado pelo Decreto $n^{\circ} 51.335$, de 4 de outubro de 1961, foi sucessivamente al terado pelos Decretos ns. 51.403 , de 5 de fevereiro de $1962,51.460$, de 30 de abril de $1962 ; 51.570$, de 19 de outubro de 1962, 51.649, de 7-1-63 e 51.733, de $21-2-63$.

4. A Lei n $\mathrm{n}^{\circ}$.345, de 1964 , estabeleceu que a aplicação de seus disposi tivos às Autarquias dependeria da revisão dos respectivos quadros.

5. Na impossibilidade de obter esclarecimentos, em prazo curto, para o aclaramento das diversas situações funcionais consignadas no trabalho elaborado pelo Ministério da Viação e Obras Públicas em cumprimento ao diploma legal acima referido, a Comissão de Classificação de Cargos deliberou aprovar, em caráter provisório, o Quadro de Pessoal com a constituição proposta pelo referido Ministério (Resolução n ${ }^{\circ} 260$ daquele órgão colegiado, publicada no Diário Oficial de 9-2-965) até que se complete a revisão.

6. Propôs, então, êste Departamento a expedição de ato que autorizasse a APRJ a aplicar aos tuncionários do respectivo Quadro o aumento concedido pela Lei $\mathrm{n}^{\circ} 4.345$, de 1964 , acentuando, na oportunidade, que a revisão do Quadro de Pessoal deveria implicar também na revisão dos casos de aposentadoria havidos após a vigência do Decreto número 51.403 , de 5 de fevereiro de 1962 (EM $\mathrm{n}^{\text {\% }} 84$, de $4-2-65$, publicada no $D O$ de 11 seguinte).

7. Resultou dêsse expediente a assinatura do Decreto $\mathrm{n}^{\circ} 55.740$, de 10 de fevereiro de 1965 , que estabeleceu no art. $5^{\circ}$, verbis:

«A execução do disposto neste decreto determinará a revisão das aposentadorias concedidas a funcionários da APRJ após a vigência do Decreto $\mathrm{n}^{\circ} 51.403$, de 5 de fevereiro de 1962, na hipótese 
de ser modificada a situação do cargo antes ocupado pelo inativo».

8. Manifestaram-se a respeito da inteligência dêsse dispositivo a Procuradoria da APRJ e a Assessoria Juridica do Ministério já citado, ambos no sentido de que a revisão das aposentadorias só se deverá efetivar após a execução do disposto naquele decreto, considerada como tal a revisão definitiva e não a aprovação provisória do enquadramento.

9. Nessa ordem de idéias, concluiram aquêles órgãos juridicos por que fôsse aplicada a Lei $\mathrm{n}^{\circ} 4.345$, de 1964, aos inativos, com base nos niveis sôbre os quais vinham sendo calculados os proventos de aposentadoria antes de entrar em vigor aquela lei.

10. Com a primeira conclusão, não concorda, data venia, êste Serviço. Se o Decreto n 55.748, de 1965, considerou sem efeito os decretos que introduziram alterações no sistema de classificação de cargos da Administração do Pôrto do Rio de Janeiro, a partir do Decreto númes ro 51.403 , de 1962 , as aposentadorias ocorridas após a vigência dêsse decreto estão automàticamente passiveis de revisão, desde que efetivadas na base das alterações introduzidas no sistema de classificação de cargos aprovado pelo Decreto $\mathrm{n}^{\circ}$ 51.335, de 1961. Dai a imposição de que sejam revistas as aposentadorias desde que se tenha modificado a situação do cargo antes ocupado pelo inativo com a superveniência do Decreto $\mathrm{n}^{\circ} 55.748$, de 1965 .

11. Constitui a execução do disposto no Decreto 55.748 , citado, não só a revisão definitiva do quadro a ser aprovado em época futura, como a imediata manutenção da classificação provisória Constante da Resolução número 260 , da CCC.

12. A circunstância, apontada pela Procuradoria da APRJ, de que da relação nominal aprovada pela referida Comissão constam ocupantes de cargos criados por decretos considerados nulos, não autoriza concluir, como pretende aquêle órgão juridico (fls. 25), que o art. $3^{\circ}$ do Decreto $\mathrm{n}^{\circ} 55.748$, de 1965 , apenas revogou os decretos impugnados.
Do mesmo ato convém transcrever o art. $6^{\circ}$ :

«O disposto neste decreto não homologará situações funcionais que, em virtude da revisão determinada no Decreto $\mathrm{n}^{\circ} 54.004$, de 3 de julho de 1964, forem consideradas nulas, ilegais ou contrárias a normas admitrativas em vigor».

13. Essa norma alcança também os provimentos em cargos criados pelos atos iłmpugnados. Enquanto êsses provimentos foram mantidos em caráter provisório, o mesmo Decreto $\mathrm{n}^{2} 55.748$, em relação aos inativos, não permitiu a continuidade da situação, ainda que provisòriamente. A anulação dos decretos modificadores do enquadramento afetou fundamentalmente a situação dos aposentados antes atingidos pelas modificações. Afigura-se, pois, a êste Serviço imposição imediata a revisão das aposentadorias afetadas.

14. Essa conclusão parece a mais lógica, atentando-se para o fato de que é maior a probabilidade de prevalecer, na revisão definitiva, o enquadramento provisório, ora em vigor, do que o enquadramento anterior ao Decreto número 55.748 , de 1965 .

15. Todavia, essa não é a indagação principal que se há de solucionar para a aplicação dos arts. $21, \mathrm{n}^{2} 7 \mathrm{e}$ 31 da Lei $n^{\circ} 4.345$, de 1964.

16. $\mathrm{O}$ art. $5^{\circ}$ do Decreto número 55.748 , de 1965 , visou à regularização de situações criadas por atos considerados nulos e que forçosamente terão de ser de imediato corrigidas.

17. Trata-se, pois, de revisão dos atos de aposentadoria expedidos nas condições mencionadas. Já os dispositivos da Lei número 4.345 , de 1964 , acima citados, referem-se a reajustamento de proventos para fins de concessão de aumento.

18. Portanto, deverá indagar-se se é cabivel a execução dêsses dispositivos com relação aos inativos da AFRJ, em face da atual situação do pessoal ativo daquela Autarquia.

19. No entender dêste Serviço, a situação é idêntica àquela surgida com relação aos aposentados de órgãos da 
adlministração direta que, antes do enquadramento definitivo, tiveram os cargos integrantes dos respectivos quadios classificados em caráter provisório, na forma do Decreto $\mathrm{n}^{\circ} 49.160$, de 1 de novembro de 1960 .

20. Nesses casos não houve regra legal ou regulamentar que probisse ou determinasse a revisão dos proventos. Correta seria, portanto, a conclusão favorável como também a contrária à aplicação dos arts. $21, \mathrm{n}^{\circ} 7$ e 31 da Lei $\mathrm{n}^{\circ} 4.345$, de 1964.

21. Todavia, a fim de ser observada a uniformidade de critério que deve presidir a solução dos casos relativos aos servidores federais, seria conveniente adotar-se para os autárquicos a mesma orientação que vem sendo seguida com relação aos funcionários da administração centralizada.

22. Para êsse efeito, deverá o Ministério da Viação e Obras Públicas articular-se com a Diretoria da Despesa Pública que é órgão competente para dizer da matéria.

23. Finalmente, embora não seja esta pròpriamente a questão que deu origem à consulta, convém dirimir a dúvida levantada pela Divisão do Pessoal da APRJ no trecho da informação de
fls. 6, abaixo transcrito:

«Entretanto, se fôr aplicado êste percentual de $100 \%$ sôbre o valor dos niveis estabelecidos pela Lei $\mathrm{n}^{\circ} 4.242-63$, os proventos dos inativos terão uma redução, se se atentar para o principio de que o cálculo dos ganhos da inatividade deve ser feito na mesma proporção dos vencimentos que percebe o pessoal da ativa (art. 10 da Lei $\mathrm{n}^{\circ} 2.622$, de $18-10-55) \ldots \gg$

24. E' preciso acentuar que a Lei $n^{\circ} 2.622$, de 1965, não determina que sejam igualados os proventos da inatividade aos vencimentos dos funcio nários ativos, mas sim estabelece que o reajustamento será efetuado à base da t€tribuição paga aos servidores em atividade, a fim de que os proventos sejam atualizados.

Pagá-la ao funcionário que a ela tem direito, quando no gôzo de férias, não infringe, pois, aquêle dispositivo legal.
12. Concluindo, entende êste Serviço, de acôrdo com o parecer da Contadoria-Geral da República, citado, que o servidor que estiver percebendo gratificação em virtude da natureza do serviço de suas atribuições continuará fazendo jus. à mesma vantagem quando no gôzo de férias regulamentares ou instituidas em lei especial.

Brasilia, 16 de setembro de 1966. Myriam Sampaio Lofrano, Chefe do SRLF.

De acôrdo. Submeto à consideração do Senhor Diretor-Geral, propondo a restituição do processo ao Departamento dos Correios e Telégrafos, caso o parecer mereça aprovação.

Brasilia, 16 de setembro de 1966. Paulo César Cataldo, Diretor de Divisão do Regime Juridico do Pessoal.

Solicito o parecer da douta Consultoria Juridica - DASP., em 16-9-66 - a) Luiz Vicente B. de Outo Prêto, Diretor-
Geral.

Prende-se a consulta formulada neste processo a problema alusivo a servidores aposentados da Administração do Pôrto do R'o de Janeiro, no que se refere a cálculos para o reajustamento previsto na Lei 4.345, de 1964 .

2. Antes de entrar no mérito da questão, convém se faça um retrospecto do que ocorreu sôbre a implantação do sistema de classificações de cargos na citada autarquia.

3. Cabe-me esclarecer, inicialmente, que, pelo Decreto $\mathrm{n}^{\circ} 51.335$, de 4 de outubro de 1961, foi aprovado, em cas ráter definitivo, o enquadramento dos cargos pertencentes ao quadro de pessoal da Administração do Pôrto do Rio de Janeiro, tendo sido o mesmo expedido após prévió pronunciamento da Comissão de Classificação de Cargos e da Divisão de Classificação de Cargos, órgãos êsses instituidos pela Lei 3.780 , de 1960 , para zelar pela execução das medidas na mesma previstas e fiel observância dos preceitos nela contidos.

4. Não obstante a autenticidade do mencionado ato, aprovado com plena observância do disposto no art. $56 \mathrm{da}$ Lei $n^{\circ} 3.780$, de 1960 , inclusive no que 
tange às peculiaridades da administração do pessoal daquela Autarquia, decretos outros foram baixados, à revelia dos órgãos de Classificação de Cargos, como os de ns. 51.403, de 5-2-62, 51.460, de $30-4-62,51.570$, de $19-10-62,51.649$, de $7-1-63$ e 51.733 , de $21-2-63$, que introduziram profundas modificações no enquadramento definitivo inicial, com infringência mesmo do preceito estabelecido no art. 56, $\S 1^{\circ}$ da Lei 3.780 , de 1960 , verbis:

«Art. $56 \ldots \ldots \ldots \ldots \ldots \ldots . . . . .$.

$\S 1^{\circ}-$ Os niveis de vencimento e salário não ultrapassarão os valôres correspondentes no serviço c.vil do Poder Executivo, confrontados os cargos e categorias de atribuições semelhantes ou idênticas».

5. Foi a constituição de situações dessa natureza que ensejou a inserção na Lei 4.345 , de 1964 , de dispositivo tendente a obter a regularização e o restabe'ecimento dos princípios constantes da Lei 3.780, de 1960, quais sejam os arts. 19 e 20, que condicionam a sua aplicação às autarquias à revisão geral dos respectivos quadros.

6. Com base nos aludidos dispositivos e respectiva regulamentação - Decreto $\mathrm{n}^{\circ}$ 54.004, de 3-7-64, foi assinado o Decreto $\mathrm{n}^{\circ}$ 54.083, de 31-7-64, que, aprovando a revisão do Quadro de Pessoal da Administração do Pôto do Rio de Janeiro, restabelecia a situação oriunda do Decreto 51.335, de 4-10-61, com anulações simultâneas dos Decretos ns. $51.403-60,51.460-62,51.570-62$, $51.649-63$ e $51.733-63$.

7. Reconhecendo, todavia, os reflexos negativos que acarretariam as medidas radicais, no mesmo previstas, ao bom andamento dos serviços afetos àquela autarquia, foi proposta por êste Órgão a expedição do Decreto $\mathrm{n}^{\circ} 54.083$, de 31-7-64, com o fito de restabelecer os atos por êle tornados sem efe:to e sujeitá-los à revisão, que seria promovida pelo Ministério da Viação e Obras Públicas, no prazo de 60 (sessenta) dias, com a audiência dêste Departamento.

8. Previa, ainda, o aludido decreto que a aplicação dos novos valôtes instuidos na Lei 4.345 , de 1964, aos ser- vidores, cuja situação estava regulada pelos mencionados atos, ficasse condicionada à aprovação dessa revisão, mediante ato do Presidente da República.

9. Foi, então, baixado o Decreto número 55.748 , de $10-2-65$, resultante de proposta apresentada pelo Ministério da Viação e Obras Públicas, em cumprimento ao disposto no Decreto número 54.273, de 9-9-64.

10. O trabalho encaminhado, émbora resultante de estudos realizados por uma com.ssão especial, designada pelo Senhor Ministro da Viação, não se fazia acompanhar de elementos que se tornavam indispensáveis, e, como os servidores daquele ente autárquico vinham percebendo seus vencimentos na base da Lei 4.242 , numa angustiosa expectativa pela aplicação da Lei 4.345 , admitiram a DCC e a CCC a aprovação, em caráter provisório, do enquadramento do pessoal da Administração do Pôrto do Rio de Janeiro.

11. Conforme se fêz ressaltar na Exposição de Motivos n 89, de 4-2-65, dêste Orgão e dirigida ao Senhor Presidente da República, a medida concretizada através do Decreto número 55.748 , de 1965 , teve como escopo propiciar àquela autarquia a oportunidade de aplicação das vantagens financeiras decorrentes da Lei 4.345, de 1964, aos seus servidores, sem prejuizo das correções que se impuserem na revisão geral a realizar, nos têrmos dos artigos 19 e 20 da mesma, não acarretando, assim, aquela aprovação, em caráter provisório, homo'ogação de situações funcionais passiveis de serem consideradas nulas, por ilegais e contrárias às normas administrativas em vigor.

12. O Decreto $n^{\circ} 55.748$, de 10 de fevereiro de 1965, é legitimo e é resultado do fiel cumprimento de expressas determinações contidas na Lei 4.345, de 1964.

13. Se, na Administração do Pôrto do Rio de Janeiro e na maioria dos casos, os servidores em atividade tiverem, por fôrça da Resolução 260 da CCC e do Decreto $55.748-65$, as suas situações revistas, colocando-as dentro da sistemática do Plano de Classificação de Cargos, instituida pela Lei 3.780 , considerando, portanto, sem qualquer efeito as 
modificações oriundas daqueles decretos eivados de nulidade, qual a justificativa para deixar permanecer situações irregulares de inativos, concretizadas com base nas alterações advindas dos decretos impugnados, que feriram frontalmente disposição legal expressa?

14. O fato de ter sido o enquadramento dos servidores, ainda pertencentes ao Quadro, aprovado em caráter provi sório, não justifica se mantenham aquelas situações irregulares, fazendo incidir sôbre proventos, indevidamente percebidos, o reajuste previsto em lei posterior (Lei 4.345), que expressamente determina sua incidência após as correções ou revisões que se fazem necessárias.

15. Por outro lado, não pode causar qualquer estranheza a revisão das aposentadorias à base do enquadramento provisòrialmente aprovado, porquanto a Diretoria da Despesa Pública, através do Serviço de Inativos, fêz, em 1960 e 1961 , com base nos enquadramentos provisórios dos servidores dos Ministérios, as revișões de aposentadorias.

16. Assim exposto, urge sejam revistas as aposentadorias feitas na Administração do Pôrto do Rio de Janeiro, com fundamento nos decretos citados e não se procurar convalidá-las com a incidência de reajustes previstos elm lei posterior que determina prévia revisão.

Brasilia, 22 de novembro de 1966. Luiz Rodrigues, Consultor Jurídico.

De acôrdo com os pareceres da DRJP e da Consultoria Juridica dêste Departa-
mento.

2 - Restitua-se ao DA do Ministério da Viação e Obras Públicas. DASP, em 27-11-1966 - As.) Luiz Vicente B. de Outo Prêto, Diretor-Geral.

\section{PROCESSO N* 4.379-66}

Decreto Legislativo $\mathrm{n}^{\circ} 18$, de 1961 Interpretação do seu art. $1^{\circ}$, alinea c.

Constitucionalidade dêsse dispositivo, desde que se considerem sòmente as punições disciplinares e faltas ao serviço ali contempladas com as que oferecem nexo causal com fatos determinantes da ação pública em defesa do Estado.
Pronunciamentos reiterados nesse sentido de uma das turmas (terceira) da Suprema Côrte.

\section{PARECER}

\section{I}

Com invocação do art. $1^{\circ}$, ilinea $c$, do Decreto Legislativo $\mathrm{n}^{\circ} 18$, de 15 de novembro de 1961, funcionário do $\mathrm{Mi}$ nistério da Fazenda solicita averbação, no seu assentamento individual, como de efetivo exercicio, de todos os periodos em que estêve licenciado para tratamento de saúde, durante o lapso de tempo mencionado no aludido Decreto Legislativo (de 16 de julho de 1934 a 2 de setembro de 1961).

2. A Divisão do Regime Jurídico do Pessoal dêste Departamento (D. R. J. P.), opinando sôbre o pedido, ressalta o pronunciamento administrativo que concluiu pela inconstitucionalidade da alínea c do art. $1^{\circ}$ do citado Decreto Legislativo (Parecer número E-7, de 15 de março de 1962 do então Dr. Consultor-Geral da República, publicado no Diário Oficial de 13 de abril do mesmo ano, às págs. 4.270 a 4.272 ), do que, entretanto, discorda o Excelso Supremo Tribunal Federal, consoante se verifica do acórdão unânime do seu Tribunal Pleno, proferido em 10 de agôsto de 1964, no Recurso de Mandado de Segurança n 12.539 , do Distrito Federal, de que foi relator o eminente Ministro Hahnemann Guimarães (fôlhas 17 usque 26).

3. Dai a reabertura da matéria no âmbito ad/ministrativo, desde que a manifestação jurisdicional, embora casuistica, tem, no caso, repercussão normativa, por importar na decisão in genere, da constitucionalidade do ato legislativo de que se trata.

4. Nesse sentido, propõe a DRJP a audiência da douta Consultoria-Geral da República, com a manifestação prévia desta Consultoria Juridica.

5. A alinea $\mathrm{c}$ do art. $1^{\circ}$ do Decreto Legislativo $\mathrm{n}^{\circ} 18$, de 1961 , cuja interpretação constitui objeto dêste processo, tem a seguinte redação:

«Art. $1^{\circ}$ São anistiados: 
c) todos os servidores civis, militares e autárquicos que sofreram punições disciplinares ou incorreram em faltas ao serviço no mesmo periodo, sem prejuizo dos que foram assíduos».

6. A constitucionalidade dessa preceituação foi matéria efetivalmente decidida no aresto a que se faz menção no item 2 dêste parecer, reiterado por vários outros julgados da Terceira Turma do Excelso Supremo Tribunal Federal, a que me reportarei mais adiante. Mas a in terpretação dada nesses acórdãos, em divergências com o que decidiu o Tribunal Pleno, em 10 de agôsto de 1964 , no Recurso de Mandado de Segurança $\mathrm{n}^{\circ} 12.539$, a que já se aludiu, é a de que as punições disciplinares e as faltas ao serviço contempladas no dispositivo transcrito no item anterior devam guardar relação com fatos que determinaram a ação pública em defesa do Estado, vale dizer, que tais faltas tenhalm conexâo com crimes politicos cometidos.

7. Assim também me parece, por se tratar de anistia, que é medida essencialmente política, embora desconheça eu decisão do Tribunal Pleno do Pretório Excelso que a tenha acolhido, desde que a de que se juntou cópia nesse processo é, como já se disse, divergente, pois que não condiciona essas punições e faltas à existência de nexo causal com os crimes politicos mencionados na alínea a do art. $1^{\circ}$ do citado Decreto Legislativo.

8. As decisões da Terceira Turma do Supremo Tribunal Federal, tomadas à unanimidade, no sentido já referido, são as seguintes:

a) no Recurso de Mandado de Segurança $\mathrm{n}^{\circ}$ 14.337, do Distrito Federal, relatado pelo Ministro Prado Kelly «Diário da Justiça» de 28 de abril de 1966, pág. 1.346, de que extraio o seguinte excerto de sua ementa:

«As punições disciplinares que a lei manda esquecer (artigo $1^{\circ}, c$ ) são as de nexo causal com us fatos determinantes da ação pública em defesa do Estado: não as que derivam de motivos estranhos àqueles acontecimentos»;

b) no Recurso de Mandado de Segurança $\mathrm{n}^{\circ}$ 16.179, do Estado da Gua- nabara, de que foi relator o Ministro Luiz Galloti «Diário da Justiça» de 15 de junho de 1966, pág. 2.100, cuja ementa é a seguinte:

«Anistia concedida pelo Decreto Legislativo 18.

Sua aplicação a punições disciplinares depende de que estas tenham nexo causal com crimes politicos»;

c) no Recurso em Mandado de Segurança $n^{\circ} 16.035$, do Estado da Guanabara, relatado pelo Ministro Hermes Lima «Diário da Justiça» de 12 de outubro de 1966 , pág. 3.510 , de que reproduzo a ementa:

«Faltas ao serviço. Anistia. As faltas ao serviço de que trata o Decreto Legislativo $\mathrm{n}^{\circ} 18$, de 1961 , são as que mantêm nexo causal com os fatos determinantes da ação pública em defesa do Estado. Recurso desprovido»;

d) finalmente, idêntica é a decisão do Recurso de Mandado de Segurança número 15.976, do Estado da Guanabara, de que foi relator o Ministro Luiz Gallotti, na conformidade do que se contém no «Diário da Justiça», de 9 de novembro fluente, à pág. 3.873 .

9. Esta a orientação que julgo aplicável à espécie, harmonizando a norma legislativa com os princípios que informam a medida politica de que se cogita, de modo a que se não vislumbre na disposição a menor eiva de inconstitucionalidade.

10. No caso dos autos, nenhuma conexão se alega existente entre as faltas ao serviço, por motivo de doença do requerente, ocorridas naquele periodo, com qualquer fato politico de que fôsse êle participante e em razão do qual houvesse sofrido ação pública punitiva. Daí, ao que entendo, não merecer o pedido deferimento.

11. São as considerações que me cabe oferecer a propósito da consulta sôbre a qual, entretanto, melhor dirá a douta Consultoria-Geral da República, se se entender conveniente a sua audiência.

$E^{\prime}$ o meu parecer.

S.M.J. 
Brasilia, 25 de novembro de 1966. Clenicic da Silva Duarte, Consultor Jurídico.

«De inteiro acôrdo com o parecer da Consultoria Juridica».

2. Faça-se expediente restituindo o processo ao Gabinete Civil da Presidên cia da República, que, se entender necessário, promoverá a audiência da douta Consultoria-Geral.

\section{A DRJP, para providenciar.}

DASP, 30-11-66. - Luiz Vicente B. de Ouro Ptêto, Diretor-Geral.

\section{PROCESSO No $8.281-66$}

Aposentadoria com fundamento no art. 180 do Estatuto dos Funcionários.

Não se consideram, para êsse efeito, os cargos em comissão ou funções gratificadas exercidos em pessoas juridicas de direito público distintas, a menos que haja disposição legal expressa em sentido contrário, como ocorre entre a União e as autarquias federais (art. $1^{\circ}$, in fine, da Lei número 3.050, de 1952).

As funções em comissão ou gratificadas exercidas na Prefeiturą do Distrito Federal não são consideradas, para efeito do art. 180 do Estatuto dos Funcionários, na aposentadoria de servidor público
federal.

\section{PARECER}

\section{I}

Funcionário do Ministério da Agricul tura, pôsto à disposição da Prefeitura do Distrito Federal, onde exerce há imais de dois anos, a função em comissão de Diretor de Divisão, simbolo FG-3, solicitou aposentadoria, na forma do art. 180 do Estatuto dos Funcionários Públicos Civis da União, com as vantagens dessa função.

2. Sôbre o pedido, manifestou-se a Divisão de Regime Juridico do Pessoal, dêste Departamento, que concluiu contràriamente à solicitação, embora haja sugerido, a propósito, a audiência desta Consultoria Juridica, o que ora vem determinar o Senhor Diretor-Geral.

\section{II}

3. Para o benefício concedido pelo art. 180 do Estatuto dos Funcionários citado, consistente na aposentadoria, após mais de 35 anos de serviço público, com as vantagens de cargo em comissão ou de função gratificada, nas condições ali expressas, só se consideram, de um modo geral, salvo disposição legal em contrário, os cargos e funções exercidos na mesma pessoa jurídica de direito público responsável pelo processamento da aposentadoria.

4. Nesse mesmo sentido, opinei em parecer emitido em 24 de julho de 1956 no Processo $n^{\circ} 1.116-56$, publicado no Diário Oficial de 8 de agôsto de 1956, às páginas $14.931 \mathrm{e} 14.932$ (cf., também, meus Estudos de Direito Administrativo, Imprensa Nacional, 1960, vol. I págs. 125 a 127), de que me permito extrair o seguinte excerto:

$\ll D e$ fato, as vantagens outorgadas pelo art. 180 do Estatuto dos Funcionários exigem òbviamente que os cargos ou funções gratificadas. de que trata tenham sido desempenhados na mesma entidade de direito público. Não há, assim, comunicabilidade entre duas pessoas jurídicas diversas, colmo a União e a autarquia mencionada, com o fim de se considerar o exercício de cargo ou de função gratificada numa, para surtir efeito em outra. A norma do art. 180 do citado Estatuto é de natureza excepcional e, assim, demanda interpretação restritiva» (Diário Oficial e livro cits. páginas 14.932 e 126 , respectivamente).

5. Mais tarde, entretanto, o legislador entendeu de permitir essa comunicabilidade, mas tão-sòmente entre a União e as autarquias federais, como se acha expresso no art. $1^{\circ}$, in fine, da Lei $n^{\circ} 3.050$, de 21 de dezembro de 1956, onde se dispõe:

«Art. $1^{\circ}$ A função de administrador das Estradas de Ferro Leopoldina, Santos e Jundiai e Ilhéus quando exercida por funcionário público nomeado pelo Presidente da República, será equiparada aos cardos em comissão de que trata o art. 180 do Estatuto dos Funcionários 
Públicos Civis da União ùnicamente para os fins mencionados naquele artigo, bem como os cargos em comissão nas autarquias federais, quando exercidos por servidores públicos devidamente autorizados pelo Presidente da República».

6. Daí a reprodução da mesma nor.ma no art. $5^{\circ}$ do Decreto número 41.666 , de 19 de junho de 1957, que regulamentou o art. 180 e seus parágrafos do mencionado Estatuto dos Func:onários.

7. Mas essa permissibilidade só se mantém por ter sido expressamente prevista em lei, como ressalvamos, na exposição do principio, no item 3 dêste pronunciamento.

8. Em relação a funções ou cargos em comissão, bem como funções gratificadas, exercidos na Prefeitura do Distrito Federal, não havendo norma expressa que permita essa comunicabilidade como efetivamente não há, não se poderá proceder de igual modo, desde que o Distrito Federal é pessoa juridica de direito público distinta da União (Código Civil, art. 14, número I e II) .

9. Não há, pois, como deferir a pretensão do requerente.

\section{E o meu parecer.}

\section{S.M.J.}

Brasilia, $1^{\circ}$ de dezembro de 1966. Clenicio da Silva Duarte, Consultor Jurídico.

«De acôrdo com os pareceres da DRJP e da douta Consultoria Juridica».

\section{Restitua-se ao órgão de origem.}

DASP, em 5-12-66. - Luiz Vicente $B$. de Outo Prêto, Diretor-Geral.

\section{PROCESSO No $N^{\circ}$. $017-66$}

Aprovação de proposta orçamentária do IBC por decreto do Poder Executivo, em face do disposto no art. 107 da Lei $\mathrm{n}^{\circ} 4.320$, de 1964 , e respectiva regulamentação.

Competência do DASP para apreciar a proposta, submetendo-a, em seguida, à aprovação do Presidente da República.
A gratificação selmestral concedida aos servidores do IBC, condicionada às possibilidades da autarquia, ainda permanece em vigor, embora se trate de disposição constitutiva de verdadeiro privilégio. Enquanto não revogada, não há como negar eficácia à disposiçáo legal especifica, que encontra apoio no art. 15, $\S 1^{\circ}$, da Lei $\mathrm{n}^{\circ} 4.345$, de 1964.

\section{PARECER}

\section{I}

A Divisão de Orçamento e Organização do DASP (D. O.) solicita a audiência desta Consultoria Juridica a propósito de impugnação que fêz na proposta orçamentária do Instituto Brasileiro do Café para o exercicio de 1966.

2. Motivou a consulta a dotação prevista pela autarquia para atender a despesas com pagamento de gratificação semestral aos seus funcionários, o que, segundo a D. O. infringindo disposições da Lei $\mathrm{n}^{\circ} 4.345$, de 26 de junho de 1966 , e pronunciamento da ilustrada Consultoria-Geral da República (Pareceres núlmeros $124-\mathrm{H}$, de 18 de dezembro de 1964, e $30-\mathrm{GH}$, de 31 de janeiro de 1966, publicados, respectivamente, no Diário Oficial de 28 de janeiro de 1965 , à pág. 1.078 , e 18 de fevereiro do corrente ano, página 1.990).

3. O Instituto Brasileiro do Café (IBC) tomando conhecimento da impugnação, levantou, preliminarmente, a incompetência dêste Departamento, em face da Lei $\mathrm{n}^{\circ} 4.924$, de 23 de dezembro de 1965 , para continuar a examinar os orçamentos da entidade, e, no mérito, a inaplicabilidade à espécie da norma leģal invocada, (art. 16, caput) por não cogitar de vantagem por participação em lucro, ou gratificações de balanço, matéria ali contemplada, cuja interpretação foi objeto de estudo da douta Consultoria-Geral da República nos pareceres mencionados. Trata-se ao contrário, segundo a autarquia, de vantagem de outra natureza expressamente prevista nos arts. $6^{\circ}$, alínea $b$, e $7^{\circ}$ do Decretolei $\mathrm{n}^{\circ} 7.175$, de 20 de dezembro de 1944 , ainda não revogados.

\section{II}

4. A preliminar suscitada, no sentido de que não mais seria competente 
a DO dêste Departamento para examinar a proposta orçamentária do IBC, em face do que se contém na Lei número 4.924 , de 23 de dezembro de 1965 , que fixa normas para a elaboração do Esquema Financeiro das safras cafeeiras, não tem razão de ser desde que em nenhum dos dispositivos dêsse diploma legal se encontra qualquer norma contrária ao disposto nos artigos 10 , e seguintes da Lei nümero 4.320 , de 17 de março de 1964 , bem como a respectiva regulamentação baixada com o Decreto $\mathrm{n}^{\circ}$ 54.397, de 9 de outubro de 1964.

5. Os orçamentos do IBC coimo das demais autarquias deverão ser aprovados por decreto do Poder Executivo, nos têrmos do art. 107 da citada Lei $\mathrm{n}^{\circ} 4.320$, de 1964 , sujeita a tramitação das respectivas propostas às normas constantes do referido Decreto número 54.397, de 1964 , cujo $\S 1^{\circ}$ do seu art.
30 estatui:

\section{«Competirá ao Departamento Administrativo do Serviço Público o exame do cumprimento das forma- lidades legais e a apresentação dos orçałmentos, mediante projeto de de- creto, à aprovação presidencial».}

6. Não há, pois, como acolher a preliminar argüida pelo IBC, dado que nenhuma disposição legal posterior veio a conflitar com as normas constantes dos artigos 107 e seguintes da Lei $\mathrm{n}^{\circ} 4.320$, de 1964 , e sua respectiva re-
gulamentação.

\section{III}

7. No mérito, não tem razão a DO dêste Departamento. De fato, como esclarece o IBC, a yratificação impugnada não se constitui em nenhuma espécie prevista no art. 16, caput, da Lei $\mathrm{n}^{\circ}$ 4.345, de 1964, mas em vantagem de outra natureza, simples gratificação semestral, contemplada em disposições legais ainda em vigor - os artigos $6^{\circ}$ caput, alinea $d$, e $7^{\circ}$ do Decreto número 7.175, de 1944, que estabelecem:

"Art. $6^{\circ}$ Os empregados do DNC, além do salário da função, só poderão perceber: d) gratificação semestral;

Art. $7^{\circ}$ A gratificação semestral não poderá ser superior a um mês de vencimento e será concedida, nos meses de junho e dezembro, pelo presidente do DNC.

Parágrafo único. A concessão da gratificação semestral condiciona-se às possibilidades financeiras do DNC.»

8. Embora o Decreto-lei $\mathrm{n}^{0} 9.272$, de 22 de maio de 1946 , tenha determinado a dispensa do pessoal do antigo Departalmento Nacional do Café (DNC), a Lei $\mathrm{n}^{\circ} 164$, de 5 de dezembro de 1947 , que dispõe sôbre o seu aproveitamento, assegurou-lhe os direitos que por lei já gozava ao tempo da extinção da autarquia (art. $1^{\circ}$ ), criando-se, com a Lei $n^{\circ} 1.779$, de 22 de dezembro de 1952 (art. 16), o atual Instituto Brasileiro do Café, onde se deu êsse aproveitamento. E nenhuma disposição posterior, do que tenho conhecimento, revogou aquela vantagem.

9. Ora, nos têrmos do $\S 1^{2}$ do artigo 15 , in fine, da Lei $n^{9} 4.345$, de 1964 , as vantagens outras que não as contempladas no corpo do artigo foram revogadas, a menos que estivessem como no caso da consulta, expressamente previstas.

10. Havendo a previsão legal (artigos $6^{\circ}$ alinea $d$, e $7^{\circ}$ do Decreto-lei número 7.175 , dé 1944), revigorada por disposição de lei posterior (Lei n ${ }^{\circ} 164$, de 1947 , citada, art. $1^{\circ}$ ), não vejo como negar-se validade a essa disposição, quando há ressalva expressa da hipótese em legislação recente (Lei número 4.345 , de 1964, art. $\left.15, \S 1^{\circ}\right)$. Embora se trate de situação de verdadeiro privilégio, cumpre açáá-la enquanto se mantiver a vantagem excepcional con-
ferida.

E o meu parecer.

S.M.J.

Brasilia, 30 de novembro de 1966. Juridico.

De acôrdo com o parecer da Consultoria Juridica. 
2 - Encaminhe-se à $\mathrm{DO}$, para as providências cabiveis, decorrentes da orientação adotada.

DASP, em 5-12-1966 - as.) Luiz Vicente $B$, de Ouro Prêto, Diretor-Geral.

\section{PROCESSO N` $11.085-66$}

Brasilia.

Parcelas absorvidas das diárias de

- Em face de parecer da Consultoria-Geral da República, com aprovação presidencial, essas absorções não se incorporam nem mesmo aos proventos da inatividade, sendo, em conseqüência, inconstitucional o disposto no art. $5^{\circ}$ da Lei $n^{\circ} 4.019$, de 1961.

- A hierarquia do pronunciamento adlministrativo de que se trata impõe sua observância.

\section{PARECER}

\section{I}

Tendo em vista manifestações desta Consultoria Jurídica sôbre as parceles absorvidas das diárias de Brasilia, confiante opinei em parecer de 4 de julho do corrente ano, no Processo número 777-66, com cuja conclusão também concordou o meu eminente colega, Doutor Luiz Rodrigues (cf. Diário Oficial de 24 de agôsto de 1966, páginas 9.736 e 9.737 - fls. 2 e 3 do processo), funcionário do Ministério da Justiça e Negócios Interiores, que regressou ao Estado da Guanabara, mas que servira nesta Capital, quando fêz jus a absorção das referidas diárias, requereu o pagamento dessa vantagem.

2. O pedido, por solicitação do Ministério a que pertence o suplicante, foi submetido à apreciação dèste Departamento, por isso que os têrmos do art. $2^{\circ}$ do Decreto $n^{\circ} 54.012$ de 10 de junho de 1964, levam a conclusão diversa. Em consequiência, o Sr. Diretor-Geral determinou a audiência desta Consultoria Juridica.

\section{II}

3. A matéria tem ensejado mais de um estudo de minha parte, quer no pro- nunciamento citado, quer no parecer que emiti no Processo número 7.488-64, publicado no Diário Oficial de 18 de agôsto de 1964 , às páginas 7.339 a 7.341 , inclusive ao impugnar disposições do referido Decreto número 54.012, de 1964.

4. As considerações que me têm levado a êsses pronunciamentos se originam de convicção firme que, a respeito do assunto, cada vez mais se me estranha, embora não haja conseguido convencer a douta Consultoria-Geral da República, que se tem mantido, ao propósito, em terreno antagônico.

5. Mais uma vez, assim, vem de manifestar-se a ilustrada ConsultoriaGeral da República, já agora no mesmo processo em que houve o meu último pronunciamento, em que se baseou o pedido em exame. $\mathrm{E}$, não obstante reiterados pronunciamentos administrativos unânimes do Supremo Tribunal Federal, em processos de aposentadoria não só dos seus eminentes Ministros como de funcionários administrativos daquele Pretório Excelso, entendeu Sua Excelência que as parcelas absorvidas das diárias de Brasilia não incorporam nem mesmo aos proventos da inatividade. (Parecer $\mathrm{n}^{\circ}$ 414-H, de 12 de outubro de 1966, publicado no Diário Oficial de 18 de novembro próximo findo).

6. Como se vê, a conclusão da douta Consultoria-Geral da República importa no reconhecimento da inconstitucionalidade do art. $5^{\circ}$ da Lei número 4.019 , de 20 de dezembro de 1961, pois que êsse preceito legal expressamente dispõe de modo contrário.

7. Ainda que esta Consultoria Juridica, não obstante o muito respeito que lhe merece o eminente titular do órgão supremo de consulta juridica do País, não se tenha, data venia, convencido das razões ali expostas, só lhe resta como não poderia deixar de ser, acatar êsse reiterado pronunciamento, que deverá nortear as decisões administrativas de grau inferior.

8. Em face do exposto, não pode ser deferida a pretensão do requerente.

$\mathrm{E}^{\prime}$ o meu parecer.

S.M.J. 
Brasilia, 2 de dezembro de 1966 Clenício da Silva Duarte, Consultor Jurídico.

De acôrdo com a conclusão final do parecer.

2. Os pronunciamentos da Consultoria-Geral da República, aprovados pelo Senhor Presidente da República, têm fôrça normativa e devem ser, obrigatòriamente, respeitados por todos os órgãos de Administração Pública Federal. 3. Restitua-se à DP do MJNI. DASP, 7 de dezembro de 1966 . Luiz Vicente B. de Ouro Prêto, Diretor-
Geral. 